\title{
Effect of growth regulators and sowing date on the agronomic performance of corn hybrids in the first cropping year
}

\section{Reguladores de crescimento e épocas de semeadura no desempenho agronômico de híbridos de milho na primeira safra}

\author{
André Prechlak Barbosa ${ }^{1 *}$; Claudemir Zucareli²; José Henrique Bizzarri Bazzo ${ }^{3}$; \\ Luiz Abilio Ribeiro Alves ${ }^{4}$; Renan Iastrenski ${ }^{5}$
}

\begin{abstract}
Growth regulators can be an important tool in corn crop management, especially in technology-intensive crops grown in densified spatial arrangements, under favorable environmental conditions, and using genotypes with greater vegetative development. The objective of this study was to evaluate the effect of growth regulators associated with sowing date on the growth characteristics, yield components, and grain yield of first-crop corn hybrids. The experiment was performed on a 2014/15 field crop, under a randomized complete block design with four replicates. Treatments were placed in a $2 \times 2 \times 3$ factorial arrangement consisting of two sowing dates (first: 09/19/2014 and second: 11/23/2014), two corn hybrids (2B610 PW and 2B810PW), and three conditions of growth regulators (control without application, 400 g a.i. ha ${ }^{-1}$ trinexapac-ethyl, and $200 \mathrm{~g}$ a.i. $\mathrm{ha}^{-1}$ clomazone, both applied when six fully expanded leaves were observed). The following characteristics were evaluated: plant height, ear insertion height, stem diameter, leaf area index, number of rows per ear, number of grains per row, number of grains per ear, ear length, ear diameter, prolificacy, thousand grain weight, and grain yield. Corn development and yield performance were altered by the interaction between sowing date, genotypes, and growth regulators. The second sowing date, which was not limited by water deficiency, resulted in better development and yield performance for the two hybrids. The $2 \mathrm{~B} 610$ hybrid had a higher yield performance than did 2B810 in the second sowing date. Trinexapac-ethyl and clomazone contributed to higher corn grain yield from the two hybrids at the first sowing date and from the 2B810 hybrid at the second date. Trinexapac-ethyl reduced the size of the 2B810 hybrid at the second date. The growth and leaf area of the 2B810 hybrid were less affected by the restrictive conditions of the first sowing date; consequently, there was a higher grain weight performance that did not allow the differentiation of yield between genotypes for this sowing date.
\end{abstract}

Key words: Plant arrangement. Genotypes. Growth reducer. Trinexapac-ethyl. Zea mays L.

\section{Resumo}

Os reguladores de crescimento podem ser uma ferramenta importante no manejo da cultura do milho, principalmente em lavouras com alta tecnologia, conduzidas sob arranjo espacial adensado, em condições ambientais favoráveis e utilizando genótipos com maior desenvolvimento vegetativo. $\mathrm{O}$

1 Prof., Pontifícia Universidade Católica do Paraná, PUCPR, Toledo, PR, Brasil. E-mail: andreprechlak@gmail.com

2 Prof. Dr., Universidade Estadual de Londrina, Departamento de Agronomia, UEL, Londrina, PR, Brasil. E-mail: claudemircca@ uel.br

3 Prof., Centro Universitário Filadélfia, UNIFIL, Londrina, PR, Brasil. E-mail: agro.bazzo@gmail.com

4 Discente, Curso de Mestrado, UEL, Londrina, PR, Brasil. E-mail: labilioalves@gmail.com

5 Discente, Curso de Agronomia, UEL, Londrina, PR, Brasil. E-mail: renaniastrenski@live.com

* Author for correspondence

Received: Mar. 04, 2018 - Approved: Aug. 21, 2019 
objetivo do trabalho foi avaliar o uso de reguladores de crescimento associados a épocas de semeadura sobre características de crescimento, componentes de produção e rendimento de grãos de híbridos de milho cultivados na primeira safra. O experimento foi conduzido em campo na safra 2014/15, sob delineamento de blocos casualizados, em esquema fatorial $2 \times 2 \times 3$, sendo duas épocas de semeadura (primeira época: 19/09/2014 e segunda época: 23/11/2014), dois híbridos de milho (2B610PW e 2B810PW) e três reguladores de crescimento (testemunha sem aplicação, trinexapac-ethyl $400 \mathrm{~g}$ i.a. ha-1 e clomazine 200 g i.a. ha ${ }^{-1}$, aplicados no estádio V6), com quatro repetições. Foram avaliadas as seguintes características: Altura de plantas, altura de inserção de espiga, diâmetro de colmo, índice de área foliar, número de fileiras por espiga, número de grãos por fileira, número de grãos por espiga, comprimento de espiga, diâmetro de espiga, prolificidade, peso da massa de mil grãos e produtividade de grãos. O desenvolvimento e o desempenho produtivo do milho é alterado pela interação entre as épocas de semeadura, genótipos e reguladores de crescimento. A segunda época de semeadura, não limitada pela deficiência hídrica, resulta em melhor desenvolvimento e desempenho produtivo para os dois híbridos. O híbrido 2B610 apresenta maior desempenho produtivo que o 2B810 na segunda época de semeadura. $\mathrm{O}$ trinexapac-ethyl e o clomazine para os dois híbridos na primeira época e para o 2B810 na segunda época favorecem a produtividade de grãos do milho. $\mathrm{O}$ trinexapac-ethyl apresenta redução de porte para o híbrido 2B810 na segunda época de semeadura. O crescimento e a área foliar do híbrido 2B810 é menos prejudicado pela condição restritiva da primeira época de semeadura, consequentemente há maior desempenho da massa de grãos que não permite diferenciação da produtividade entre genótipos para essa época de semeadura-

Palavras-chave: Arranjo de plantas. Genótipos. Redutor de crescimento. Trinexapac-ethyl. Zea mays L.

\section{Introduction}

The genetic improvement of corn advocates for the greater interception of solar radiation, achieved by reducing plant height, ear insertion height, number of leaves, length of bolting/silking period, and upright leaf angulation (OLIVEIRA et al., 2013). These changes increase the yield potential as a result of a higher tolerance to densification and lodging and responsiveness to nitrogen fertilization, optimizing the translocation capacity of photoassimilates to structures of economic interest (ARGENTA et al., 2002; COSTA et al., 2015).

Genotypes with these phenotypic characteristics and adaptations to the edaphoclimatic conditions of the growing region are not always available. In such cases, ensuring the adequacy of plant size and morphology with the use of plant regulators is an alternative (ZAGONEL et al., 2002). These regulators can be natural or synthetic, and in low doses, alter the metabolism, growth, and development of plants. Among them, stand out plant growth regulators, which are mostly products used to reduce plant growth (RADEMASCHER, 2015).
Regarding plant physiology, growth regulators alter the architectural characteristics and size, facilitate crop treatment procedures, reduce the propensity for lodging, increase resistance to densification and reduced spacing, and improve the use efficiency of resources such as water and solar radiation, which consequently increases productivity (ZAGONEL; FERREIRA, 2013; ZHANG et al., 2014).

According to Rademascher (2015), growth regulators act on different metabolic pathways, but most of them act by blocking the synthesis of the gibberellin hormone $(\mathrm{Ga})$ that is responsible for stem elongation. Among the regulators that inhibit Ga biosynthesis, trinexapac-ethyl has a prominent role and is widely used on winter cereals. This compound acts on plants by reducing elongation between nodes at the vegetative stage, interferes at the end of the metabolic pathway of gibberellic acid biosynthesis by inhibiting the enzyme 3 $\beta$-hydroxylase, drastically reducing the level of active gibberellic acid $\left(\mathrm{GA}_{1}\right)$ and increasing its immediate biosynthetic precursor $\mathrm{GA}_{20}$ (DAVIES, 1987). 
A reduction in plant growth can also be achieved with the use of hormones, as reported by Moro and Castro (1984), who observed a reduction in corn plant height with the application of ethephon (2-chloroethylphosphonic acid), and even herbicides such as 2,4-D (auxin-mimetic) (RADEMASCHER, 2015), clethodim (ACCase), imazethapyr (acetolactate synthase) (MACIEL et al., 2011), and clomazone (carotenoid synthesis inhibitors), which interfere with the malonic acid pathway, and consequently in the synthesis of terpenes (mevalonate-independent pathway) in chloroplasts, and may decrease the synthesis of $\mathrm{Ga}$ and reduce plant growth (KERBAUY, 2004).

Pricinotto (2014) and Fagherazzi (2015) identified potentialities in the use of growth reducer for corn crop, and the phytometric aspect in which the formation of more compact plants adapted to densified spatial arrangement conditions may occur, and the maintenance or grain yield increase that is associated with densified management are promising techniques for the current corn production system.

The use of plant regulators for the dense cultivation condition is intended to prevent overgrowth of plants and improve leaf architecture, which through increasing the interception efficiency of solar radiation can generate a higher corn crop yield (ZAGONEL; FERREIRA, 2013). Nonetheless, the sowing date and genotype are also important in achieving the optimal productivity.

The appropriateness of the sowing date is essential for corn because of the tropical character of the crop, particularly in subtropical regions where factors such as air temperature, water, and solar radiation have a great influence on the phenological and yield performance of plants (STRECK et al., 2012), with consequences on the growth and development and changes in the size and arrangement of plants in the field (NASCIMENTO et al., 2011). The sowing date directly interferes with the need and efficiency of growth regulators; these compounds, already widely used in winter cereals, depend on environmental conditions to act adequately (PAGLIOSA et al., 2013).

Regarding genotypes, the cycle, plant size, and leaf characteristics, such as area, angulation, and distribution are determinant in obtaining responses to the use of regulators (PRICINOTTO, 2014). The response of genetic materials to these compounds is unique and studies are needed to endorse the technology of corn production systems under different environmental conditions.

Based on the aforementioned information, the aim of this study was to evaluate the use of growth regulators associated with different sowing dates on the phytometric characteristics, yield components, and grain yield of corn hybrids cultivated in the first crop season.

\section{Material and Methods}

The experiment was conducted in the 2014/2015 crop season at the School Farm of the State University of Londrina (UEL) (23 $200^{\prime} 32^{\prime \prime} \mathrm{S}$ and $51^{\circ} 12^{\prime} 32$ " $\mathrm{W}$, average altitude $540 \mathrm{~m}$ ). The soil was characterized as Dystroferric Red Latosol (Oxisol) (EMBRAPA, 2013). The climate of the region is Cfa type, described as humid subtropical with hot summers, according to the Köppen classification.

Rainfall, solar radiation, and air temperature data during the experimental period was obtained from the meteorological station of the State University of Londrina (UEL). The crop water balance was calculated for the experimental period, and included the two sowing dates, with evapotranspiration determined by the Penman Monteith method (Figure 1). The maximum and minimum air temperature and solar radiation values during the experiment are presented in Figure 2.

Prior to the experiments, soil samples were collected from the $0-20 \mathrm{~cm}$ layers of the experimental areas for chemical analysis. The analysis presented the following data: $\mathrm{pH}\left(\mathrm{CaCl}_{2}\right)=5.50 ; \mathrm{P}=8.55 \mathrm{mg}$ $\mathrm{dm}^{-3} ; \mathrm{K}=1.60 \mathrm{cmol}_{\mathrm{c}} \mathrm{dm}^{-3} ; \mathrm{Ca}=5.30 \mathrm{cmol}_{\mathrm{c}} \mathrm{dm}^{-3}$; 
$\mathrm{Mg}=2.20 \mathrm{cmol}_{\mathrm{c}} \mathrm{dm}^{-3} ; \mathrm{Al}=0 \mathrm{cmol}_{\mathrm{c}} \mathrm{dm}^{-3} ; \mathrm{H}+\mathrm{Al}$ the stage of six fully expanded leaves (V6), with $=4.28 \mathrm{cmol}_{\mathrm{c}} \mathrm{dm}^{-3}$; chlortetracycline $=13.38 \mathrm{cmol}_{\mathrm{c}}$ $\mathrm{dm}^{-3}$ and $\mathrm{BS}=68.01 \%$.

Base fertilization consisted of the use of formulated 08:28:16 fertilizer at a dosage of 300 $\mathrm{kg} \mathrm{ha}^{-1}$. Topdressing fertilization was performed at a dose of $227 \mathrm{~kg} \mathrm{ha}^{-1}$ urea, which corresponds to $100 \mathrm{~kg} \mathrm{ha}^{-1}$ nitrogen. It is noteworthy that the total $\mathrm{N}$ applied $\left(124 \mathrm{~kg} \mathrm{ha}^{-1}\right)$ is consistent with the soil condition and crop requirement for that growing season (EMBRAPA, 2012).

Figure 1. Crop water balance according to the Penman-Monteith method, with water availability, deficit (DEF), and excess (EXC) values, referring to the experimental period (first and second sowing date: $S_{1}$ [sowing], $H_{1}$ [harvest] and $S_{2}$ [sowing]; $H_{2}$ [harvest], respectively), 2014/2015 crop year, Londrina - PR, 2016.

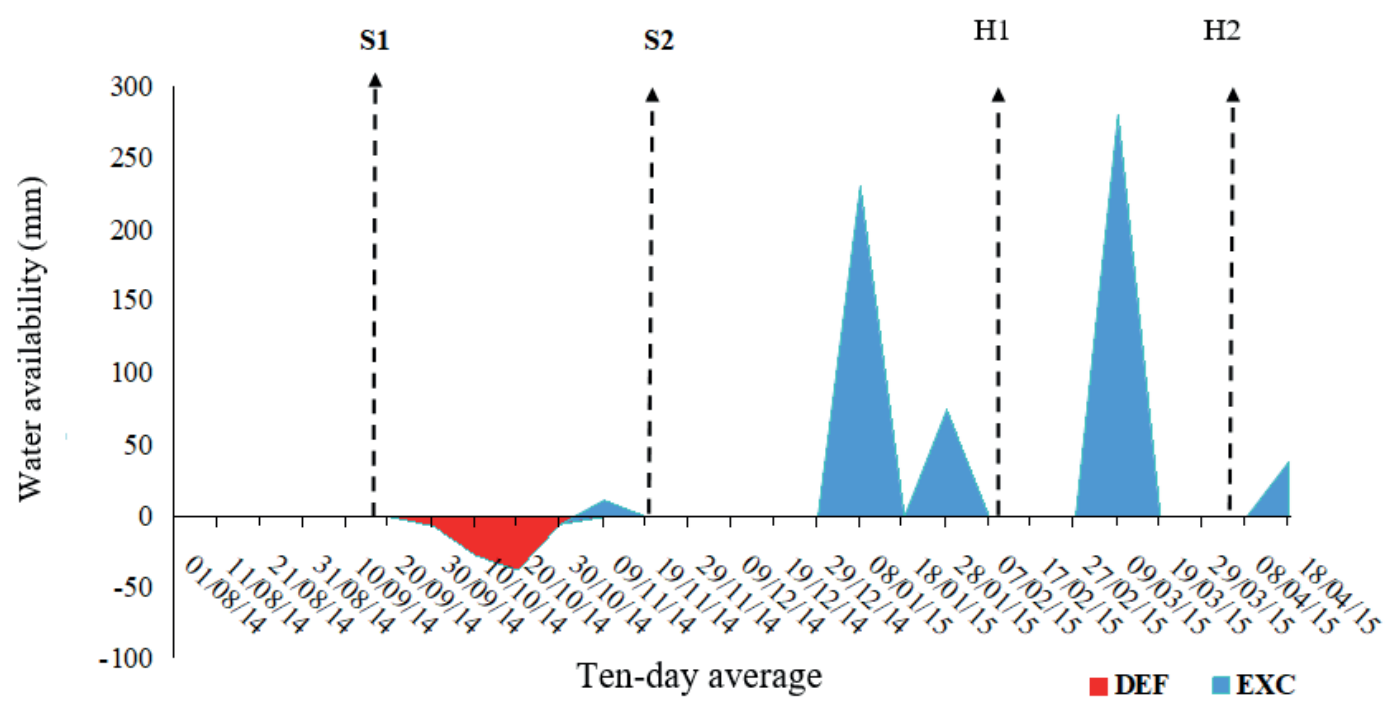

Figure 2. Solar radiation $(\mathrm{Rad})$ and minimum $(\mathrm{min})$ and maximum $(\max )$ temperatures, referring to the experimental period (first and second sowing date $-S_{1}$ [sowing], $H_{1}$ [harvest] and $S_{2}$ [sowing]; $H_{2}$ [harvest], respectively), 2014/2015 crop year, Londrina - PR, 2016.

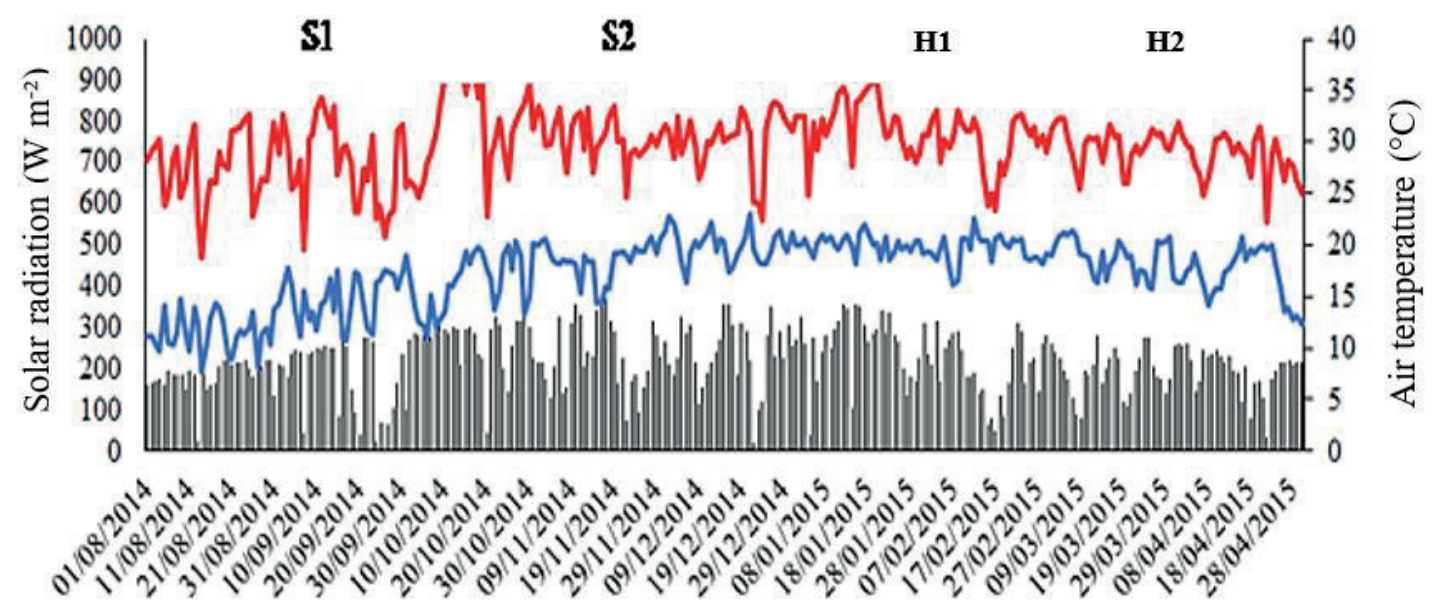

Ten-day average

- Rad —min -máx 
The experimentalareahad wheatas its predecessor and was prepared in a conventional sowing system Tillage and harrowing were performed for the initial control of weeds and homogenization of soil. The experimental plots consisted of six rows of $5 \mathrm{~m}$ in length, spaced $0.45 \mathrm{~m}$ between them, making a total area of $13.5 \mathrm{~m}^{2}$. The usable area consisted of $7.2 \mathrm{~m}^{2}$, as the lateral rows and $0.5 \mathrm{~m}$ from the ends of each plot were discarded. The population density used was the same for both hybrids $\left(75,000\right.$ plants $\left.\mathrm{ha}^{-1}\right)$.

The experiment was performed in a randomized complete block design with four replicates, and the treatments were placed in a $2 \times 2 \times 3$ factorial arrangement consisting of two sowing dates (09/19/2014 and 11/23/2014), two corn hybrids (2B610PW and 2B810PW) and three conditions of growth regulators (control without application, trinexapac-ethyl $400 \mathrm{~g}$ a.i. $\mathrm{ha}^{-1}$, and clomazone 200 g a.i. ha $\left.{ }^{-1}\right)$.

The two corn hybrids used have the following characteristics: $2 \mathrm{~B} 610 \mathrm{PW}$ is a simple type hybrid with early cycle, average plant height of $230 \mathrm{~cm}$ and high required technological level; the $2 \mathrm{~B} 810 \mathrm{PW}$ hybrid is a simple type hybrid with normal cycle, average plant height of $235 \mathrm{~cm}$, and with high required technological level.

Plant growth regulators were applied via the foliage using a $\mathrm{CO}_{2}$ pressurized backpack sprayer at constant flow rate of $200 \mathrm{~L} \mathrm{ha}^{-1}$, with $30 \mathrm{psi}$ pressure. The application was performed at stage V6, according to the scale proposed by Ritchie et al. (1993). Crop treatment procedures and weed, pest, and disease management procedures were carried out according to the recommendations of the corn crop production system (EMBRAPA, 2012).

A three-day interval was considered between the application of $\mathrm{N}$ and the application of the growth regulator in the V6 stage; however, $\mathrm{N}$ has completed its total action after about $48 \mathrm{~h}$ of its application, which avoids interference between the treatments. Moreover, no physiological alterations were found compared to those in the control plots.
The evaluations were initiated after the full flowering of the crop, when 10 plants were randomly chosen within the useful area of each plot. Plant (H) and ear insertion height $(\mathrm{EH})$ were determined in centimeters by measuring the distance between the ground surface and the base of the tassel, and the distance between the ground surface and main ear, respectively. The same 10 plants were used to evaluate the stem diameter (SD) in millimeters, which was measured with calipers in the middle third of the second internode, from the base of the plant towards the smallest diameter.

The leaf area index (LAI), expressed in $\mathrm{m}^{2}$ of leaf per $\mathrm{m}^{2}$ of soil surface, were estimated based on the measurement of the total length (L) and middle third width (W) of the photosynthetically active leaves of ten plants in the useful area of each plot. The data were submitted to the following expression, proposed by Francis et al. (1969):

$$
L A I=\frac{(0.75 \times L \times W)}{(s 1 \times s 2)}
$$

where $s_{1}$ and $s_{2}$ refer to the spacing between plants (in $\mathrm{m}$ ) in the sowing row and between the rows, respectively.

At the end of the crop cycle, the ears from the useful area of each plot were harvested and counted in order to determine the number of ears per plant. Ten ears were randomly separated from each plot, where the ear length was evaluated by measuring the length of the grain rows using measuring tape. The number of rows per ear and number of grains per row (NGR) were simply counted. The ear diameter was determined with calipers in the middle third of the ears and expressed in millimeters.

After threshing of the ears from the useful area, the thousand grain weight (TGW) and grain yield were measured. The TGW was determined according to the methodology proposed by Brasil (2009), and the grain yield was determined by weighing the grains produced in the useful area. The results were expressed in $\mathrm{kg} \mathrm{ha}^{-1}$, with both weights corrected to $13 \%$ humidity. 
Individual variance analyses were performed for all characteristics at each sowing date, and after finding the homogeneity of variances using Hartley's test, the joint analysis was performed in a triple factorial scheme. When the significant effects were detected, the factors were unfolded and compared using Tukey's test at 5\% probability.

\section{Results and Discussion}

The ANOVA showed significant effects for all variables analyzed, however with distinct responses regarding the joint or isolated action of the studied treatments: sowing date $(\mathrm{D})$, corn hybrids $(\mathrm{H})$, and growth regulators $(\mathrm{R})$ (Table 1$)$.

Therefore, the evaluated characteristics followed by the interfering factors in parentheses were as follows: plant height $(\mathrm{D} \times \mathrm{H} \times \mathrm{R})$, ear insertion height $(\mathrm{D} \times \mathrm{H})$, stem diameter $(\mathrm{D} \times \mathrm{H} \times \mathrm{R})$, leaf area index $(D \times H)$, number of rows per ear $(D \times H)$, number of grains per row $(\mathrm{D} \times \mathrm{H})$, number of grains per ear $(D \times H)$ and $(R)$, ear length $(D \times H)$ and $(R)$, ear diameter $(\mathrm{D} \times \mathrm{H})$, prolificity $(\mathrm{D})$, thousand grain weight $(\mathrm{D} \times \mathrm{H})$, and grain yield $(\mathrm{D} \times \mathrm{H} \times \mathrm{R})$.

The second sowing date (11/23/2014) presented superiority for plant height and stem diameter (Table 2 ) in both hybrids at all levels of added regulators, possibly due to the water deficiency that was observed at the beginning of the vegetative period of the first sowing date (Figure 1), and compromised the internode elongation and stem diameter growth.
It is also noteworthy that at the first sowing date, water stress affected the crop in its yield component formation period (Figure 1), affecting the potential number of ears and beginning of row multiplications per ear, with subsequent consequences on the yield parameters.

Wagner et al. (2013) stated that water availability interferes with all phenological phases of the crop, with greater or lesser intensity, and affects plant growth and development, with direct consequences on grain yield. It is significant to emphasize the importance of water for cell stretching and, consequently, for stem growth, which is related to the smaller size observed under water deficient conditions (TAIZ; ZEIGER, 2009).

When comparing the two hybrids (Table 2), it was verified that the $2 \mathrm{~B} 610 \mathrm{PW}$ hybrid showed greater height, only in the trinexapac-ethyl treatment of the second sowing date, which revealed a greater sensitivity of the 2B810PW hybrid to the use of this compound under normal water availability conditions.

There was differentiation between the genotypes for stem diameter at the first sowing date, with the 2B610PW hybrid being superior in both the control and clomazone treatments. In the second sowing date, the 2B610PW hybrid presented a larger stem diameter in the trinexapac-ethyl treatment. Costa et al. (2008) also reported developmental differences between genotypes under different water availability conditions in the vegetative period, which reaffirms the influence of these factors on the phytometric characteristics of plants. 


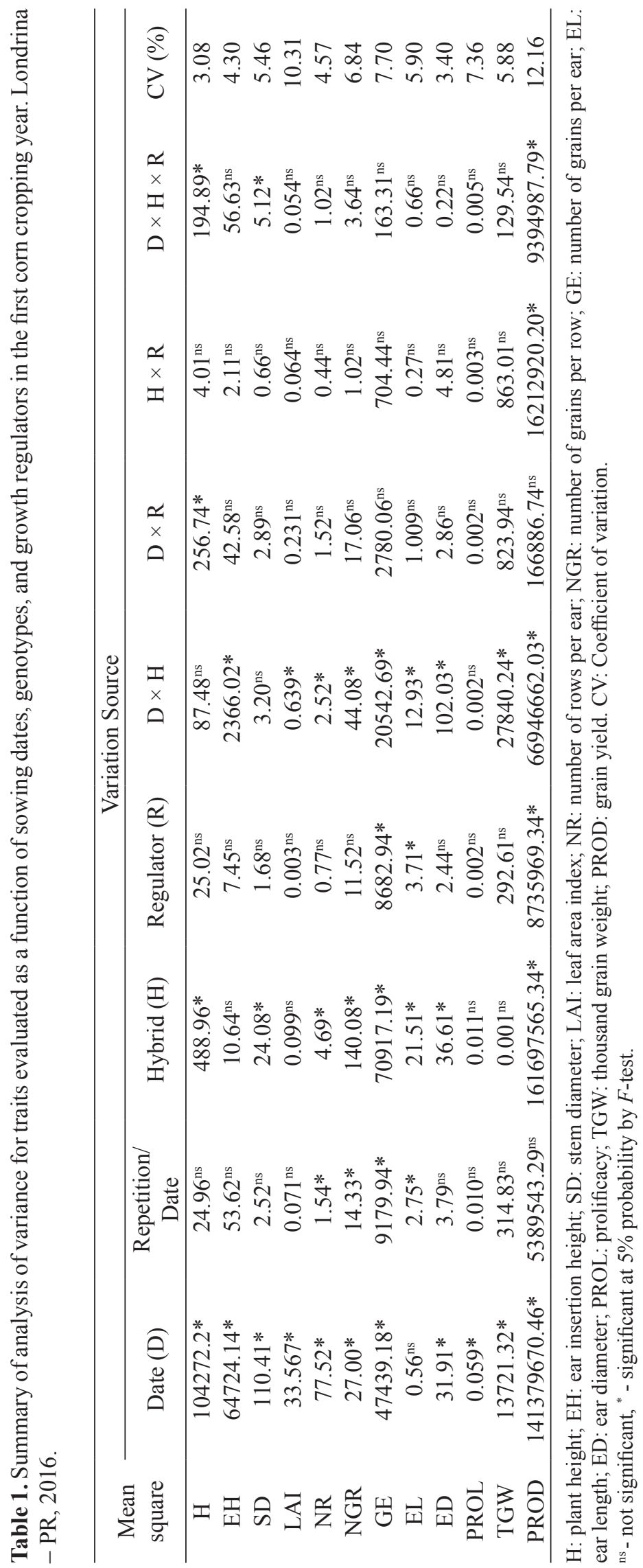


Table 2. Phytometric parameters of corn plants in response to sowing dates, hybrids, and growth regulators in the first corn cropping year. Londrina - PR, 2016.

\begin{tabular}{|c|c|c|c|c|c|c|}
\hline \multirow{4}{*}{ Sowing dates } & \multicolumn{6}{|c|}{ Hybrids } \\
\hline & \multicolumn{3}{|c|}{ 2B610PW } & \multicolumn{3}{|c|}{ 2B810PW } \\
\hline & \multicolumn{6}{|c|}{ Growth regulators } \\
\hline & Trinexapac-ethyl & Clomazine & Control & Trinexapac-ethyl & Clomazine & Control \\
\hline & \multicolumn{6}{|c|}{ Plant height $(\mathrm{cm})$} \\
\hline $1^{\text {st }}(09 / 19 / 2014)$ & $156.35 \mathrm{~b} \alpha \mathrm{A}$ & $159.30 \mathrm{~b} \alpha \mathrm{A}$ & $155.35 \mathrm{~b} \alpha \mathrm{A}$ & $159.70 \mathrm{~b} \alpha \mathrm{A}$ & $152.40 \mathrm{~b} \alpha \mathrm{AB}$ & $147.85 \mathrm{~b} \alpha \mathrm{B}$ \\
\hline \multirow[t]{2}{*}{$2^{\text {nd }}(11 / 23 / 2014)$} & $251.85 \mathrm{a} \alpha \mathrm{A}$ & $252.95 \mathrm{a} \alpha \mathrm{A}$ & $253.95 \mathrm{a} \alpha \mathrm{A}$ & $233.80 \mathrm{a} \beta \mathrm{B}$ & $246.95 \mathrm{a} \alpha \mathrm{A}$ & $250.75 \mathrm{a} \alpha \mathrm{A}$ \\
\hline & \multicolumn{6}{|c|}{ Stem diameter $(\mathrm{mm})$} \\
\hline $1^{\text {st }}(09 / 19 / 2014)$ & $19.40 \mathrm{~b} \alpha \mathrm{A}$ & $19,90 \mathrm{~b} \alpha \mathrm{A}$ & $19.90 \mathrm{a} \alpha \mathrm{A}$ & $18.00 \mathrm{~b} \alpha \mathrm{A}$ & $18.35 \mathrm{~b} \beta \mathrm{A}$ & $17.05 \mathrm{~b} \beta \mathrm{A}$ \\
\hline $2^{\text {nd }}(11 / 23 / 2014)$ & $23.75 \mathrm{a} \alpha \mathrm{A}$ & $21.80 \mathrm{a} \alpha \mathrm{B}$ & $21.20 \mathrm{a} \alpha \mathrm{B}$ & $21.40 \mathrm{a} \beta \mathrm{A}$ & $21.40 \mathrm{a} \alpha \mathrm{A}$ & $21.85 \mathrm{a} \alpha \mathrm{B}$ \\
\hline
\end{tabular}

*Averages followed by the same letter (lowercase for sowing dates, uppercase for growth regulators, and Greek letters for hybrids) do not differ statistically by the $F$-test and Tukey's test, both significant at $5 \%$ probabilities.

No differences were observed between growth regulators (Table 2) for the height of the 2B610PW hybrid plants in the two sowing dates. The 2B810PW hybrid had a higher height in the treatment containing trinexapac-ethyl at the first sowing date. This indicates that the compost was not effective in reducing the size during this period; however, under water deficit conditions, the compound may have acted in other physiological processes, such as the reduction of respiration, which could have contributed to greater plant development in relation to the control and clomazone treatments.

This information is reinforced by the study of Heckman et al. (2002), who proposed that the use of trinexapac-ethyl may partially inhibit electron transport in the mitochondria, thereby reducing cellular respiration, which indicates another potential function for the use of this compound.

This condition is reversed in the second sowing date, with a growth reduction of $13 \mathrm{~cm}$ and $17 \mathrm{~cm}$ by the action of trinexapac-ethyl and clomazone, respectively, compared to that in the control. The trinexapac-ethyl growth reducer is effective in decreasing plant size under appropriate water availability. In case of water deficiency, the compound reduces its efficiency; this information allows us to direct the recommendations of use for these compounds regarding the prevalent environmental conditions (RADEMASCHER, 2015), which corroborates with the results of the following studies: Hawerroth et al. (2015) for white oats, Fernandes (2009) for wheat, and Pricinotto (2014) for corn. On the other hand, Pagliosa et al. (2013) did not observe the effect of growth regulator on wheat because of water restrictions.

The stem diameter of the 2B810 hybrid showed no response to growth regulators. However, in the case of the 2B610PW hybrid, there was a response in the second sowing date, with a larger diameter observed in the trinexapac-ethyl treatment. Stem thickening was also found by Pricinotto et al. (2015) in corn grown under greenhouse conditions, and, in addition to internode elongation, by Souza et al. (2013) in soybean.

Fagherazzi (2015), using the trinexapac-ethyl regulator on corn crops in different phenological stages and cultivars, reported a reduction in plant height with an increase in the regulator dose by up to $800 \mathrm{~g}$ a.i. ha $^{-1}$. Moreover, there was reduction of lodging in response to the application of the trinexapac-ethyl regulator, which supports the results observed for trinexapac-ethyl in this experiment for specific dates and genotypes.

Pricinotto et al. (2015) also report that the trinexapac-ethyl regulator increased stem diameter and reduced plant height. The authors also mention 
the possibility of adopting new plant arrangements for the crop due to the size reduction provided by the plant growth regulator. This possibility is related to the change in leaf architecture (upright leaves) of modern hybrids, which maintain higher photosynthetic rates in high plant densities. Compared to classic hybrids (MARCHÃO et al., 2005), they have greater efficiency in the use of solar radiation during grain filling, and consequently have higher grain yields per area (FOLONI et al., 2015).
There was an effect of hybrids and sowing date (Table 3) on the ear insertion height and LAI. The November sowing date was superior to the September sowing date for both characteristics, due to the greater amount and distribution of rainfall and higher incidence of light, obtained between the minimum and maximum radiation during this period, particularly in the vegetative phase.

Table 3. Phytometric parameters of corn plants treated with average levels of growth regulators in response to sowing dates and hybrids in the first crop. Londrina-PR, 2016.

\begin{tabular}{|c|c|c|}
\hline & \multicolumn{2}{|c|}{ Hybrids } \\
\hline & 2B610PW & 2B810PW \\
\hline Sowing dates & \multicolumn{2}{|c|}{ Ear insertion height $(\mathrm{cm})$} \\
\hline $1^{\text {st }}(09 / 19 / 2014)$ & $66.00 \mathrm{bB}$ & $80.98 \mathrm{bA}$ \\
\hline $2^{\text {nd }}(11 / 23 / 2014)$ & $153.48 \mathrm{aA}$ & $140.38 \mathrm{aB}$ \\
\hline \multicolumn{3}{|c|}{ Leaf area index } \\
\hline $1^{\text {st }}(09 / 19 / 2014)$ & $2.70 \mathrm{bA}$ & $2.37 \mathrm{bB}$ \\
\hline $2^{\text {nd }}(11 / 23 / 2014)$ & $4.14 \mathrm{aA}$ & $4.27 \mathrm{aA}$ \\
\hline
\end{tabular}

*Averages followed by the same letter (lowercase in the column and uppercase in the row) do not differ statistically by the $F$-test at $5 \%$ probability.

A similar answer was found by Bergamaschi et al. (2010), who when comparing dry and irrigation management techniques, found about a $20 \%$ greater interception of solar radiation, i.e., higher LAI, when there was greater water availability. On the other hand, França et al. (1999) observed that water deficit negatively affected the leaf area index and dry matter accumulation in corn plants, which supports the results obtained in the present study.

There was an inverse behavior in the two sowing dates when comparing the hybrids (Table 3 ). The 2B810 hybrid showed a superior ear insertion height in the September sowing, while 2B610PW showed a superior ear insertion height in the November sowing. This result may be related to etiolation in the plants in search of solar radiation in September, resulting in a higher ear insertion; plants in competition for light have a higher ear insertion. In addition to the greater susceptibility to water stress of this genotype, the 2B610PW hybrid showed superiority in the normal water availability condition of the second sowing date.

There was no difference between genotypes in the second sowing date, however the LAI of $2 \mathrm{~B} 610 \mathrm{PW}$ was higher than that of $2 \mathrm{~B} 810 \mathrm{PW}$ in the first sowing date, which shows that under water deficiency conditions, the genotype with the largest number of leaves, and consequently larger leaf area, had its growth and development most impaired.

Nascimento et al. (2011) when analyzing sowing dates and three corn cultivars, observed differences in the LAI, with the simple hybrid DKB333 showing superiority; however, different from the present study, the later sowing date resulted in a lower leaf coverage in the area. This would be expected in this study if water conditions were normal, i.e., without excessive water restriction at the first sowing date. 
The growth regulators had an isolated effect on the number of grains per ear and ear length, with the clomazone treatment showing superiority to the control in both parameters, and equaling trinexapacethyl (Table 4). This indicates that growth regulators positively affected the partition dynamics of photoassimilates for the organ of economic interest, which increased the number of ovules in the ear and consequently the length of the ears.

Table 4. Characteristics of corn ear, average of two hybrids and two growing dates, in response to growth regulators in the first corn cropping year. Londrina - PR, 2016.

\begin{tabular}{|c|c|c|}
\hline & \multicolumn{2}{|c|}{ Hybrids } \\
\hline & 2B610PW & 2B810PW \\
\hline Sowing dates & \multicolumn{2}{|c|}{ Number of rows per ear } \\
\hline $1^{\text {st }}(09 / 19 / 2014)$ & $16.42 \mathrm{bA}$ & $15.33 \mathrm{bB}$ \\
\hline $2^{\text {nd }}(11 / 23 / 2014)$ & $18.50 \mathrm{aA}$ & $18.33 \mathrm{aA}$ \\
\hline & \multicolumn{2}{|c|}{ Number of grains per row } \\
\hline $1^{\text {st }}(09 / 19 / 2014)$ & $38.00 \mathrm{aA}$ & $32.67 \mathrm{aB}$ \\
\hline $2^{\text {nd }}(11 / 23 / 2014)$ & $34.58 \mathrm{bA}$ & $33.08 \mathrm{aA}$ \\
\hline & \multicolumn{2}{|c|}{ Number of grains per ear } \\
\hline $1^{\text {st }}(09 / 19 / 2014)$ & $618.00 \mathrm{aA}$ & $500.00 \mathrm{bB}$ \\
\hline $2^{\text {nd }}(11 / 23 / 2014)$ & $640.00 \mathrm{aA}$ & $604.00 \mathrm{aA}$ \\
\hline & \multicolumn{2}{|c|}{ Ear length $(\mathrm{cm})$} \\
\hline $1^{\text {st }}(09 / 19 / 2014)$ & $17.13 \mathrm{aA}$ & $14.75 \mathrm{bB}$ \\
\hline $2^{\text {nd }}(11 / 23 / 2014)$ & $16.31 \mathrm{bA}$ & $16.01 \mathrm{aA}$ \\
\hline & \multicolumn{2}{|c|}{ Ear diameter $(\mathrm{mm})$} \\
\hline $1^{\text {st }}(09 / 19 / 2014)$ & $46.67 \mathrm{bA}$ & $47.84 \mathrm{aA}$ \\
\hline $2^{\text {nd }}(11 / 23 / 2014)$ & $51.21 \mathrm{aA}$ & $46.56 \mathrm{aB}$ \\
\hline
\end{tabular}

*Averages followed by the same letter, do not differ statistically by the Tukey's test at $5 \%$ probability.

A similar result was reported by Pricinotto (2014), where the growth regulator used (trinexapac-ethyl) also increased the ear length, with similar effects on the number of grains per row, which is related to the increase in the number of grains per ear.

According to Oliveira et al. (2013), the change in plant leaf architecture, particularly the reduction of the insertion angle, optimizes the interception of solar radiation and improves the photoassimilate translocation dynamics, which favors the number of grains per ear. This condition is related to the alteration in the source-drain relationship, where the reduction in the growth of the vegetative part (stem) is converted to the reproductive organ.

The 2B610 hybrid had a higher number of rows per ear than did $2 \mathrm{~B} 810$ at the first sowing date
(Table 5), and both hybrids showed higher numbers of rows per ear at the second sowing date relative to those at the first sowing dates, owing to the greater water availability during this period. The 2B610PW hybrid showed a higher number of grains per row at the first sowing date.

The number of grains per ear in the $2 \mathrm{~B} 610 \mathrm{PW}$ hybrid was higher than that of $2 \mathrm{~B} 810 \mathrm{PW}$ at the first sowing date, which was determined by the superiority previously shown in the number of rows and grains per row under lower water availability conditions. On the contrary, there was no difference between hybrids in the second sowing date, even considering their cycle difference. Higher yields could be expected for longer cycles, particularly in later sowing dates, as addressed by Sangoi et al. (2010). 
Table 5. Characteristics of corn ear cultivated in response to hybrids and sowing dates in the first crop. Londrina - PR, 2016.

\begin{tabular}{ccc}
\hline & Growth regulators & Control \\
\hline Trinexapac-ethyl & Clomazine & \\
\hline $593 \mathrm{ab}$ & Number of grains per ear & $566 \mathrm{~b}$ \\
\hline & $612 \mathrm{a}$ & \\
\hline $16.19 \mathrm{ab}$ & Ear lenght & $15.51 \mathrm{~b}$ \\
\hline
\end{tabular}

*Averages followed by the same letter (lowercase in the column and uppercase in the row) do not differ statistically by the Tukey's test at $5 \%$ probability.

Regarding sowing dates, a higher number of grains per ear was found in the second date than in the first one for the 2B810PW hybrid, which allows us to classify the later genotype as being more sensitive to water deficiency if we consider the yield components. Moreover, there was no difference between dates in terms of the number of grains per ear for the 2B610 PW hybrid.

Regarding ear length, 2B610PW was found to be superior in the September sowing date. Moreover, there was an inverse behavior of genotype when comparing dates; that is, the highest length was observed for $2 \mathrm{~B} 610 \mathrm{PW}$ in the first date, while the highest length was observed for 2B810PW in the second sowing date, which demonstrates a direct relationship with the number of grains per row.

In relation to ear diameter (Table 5), the superiority of the $2 \mathrm{~B} 610 \mathrm{PW}$ hybrid in the second date stood out; the better weather conditions provided superior grain development, as shown in Figures 1 and 2.

An interaction response was observed between hybrids and sowing dates for the thousand grain weight (Table 6). There is superiority of grain mass of 2B810PW hybrid in the first date and 2B610PW in the second one. Additionally, there was a higher response in the second sowing date for the $2 \mathrm{~B} 610 \mathrm{PW}$ genotype, in contrast to the $2 \mathrm{~B} 810 \mathrm{PW}$ hybrid in the first date.

Table 6. Thousand corn grain weight and average of three growth regulators in response to hybrids and sowing dates in the first corn cropping year. Londrina - PR, 2016.

\begin{tabular}{ccc}
\cline { 2 - 3 } Sowing dates & \multicolumn{2}{c}{ Hybrids } \\
\cline { 2 - 3 } & \multicolumn{2}{c}{ Thousand grain weight $(\mathrm{g})$} \\
\cline { 2 - 3 } $1^{\text {st }}(09 / 19 / 2014)$ & $236.54 \mathrm{bB}$ & $284.71 \mathrm{aA}$ \\
$2^{\text {nd }}(11 / 23 / 2014)$ & $318.52 \mathrm{aA}$ & $270.36 \mathrm{bB}$ \\
\hline
\end{tabular}

*Averages followed by the same letter (lowercase in the column and uppercase in the row) do not differ statistically by the $F$-test at $5 \%$ probability.

These contrasting results are supported by the higher or lower tolerance of genotypes to water deficiency: 2B610PW, which maintained a higher number of rows and grains per row during water deficit, showed a reduced grain mass, whereas
2B810PW, with lower numbers of rows and grains per row, had a higher grain mass under these conditions. This is owing to the lower number of grains; there is less competition for photoassimilates, and a smaller leaf area. 
Regarding production components, the number of ears per plant, or prolificacy (Table 1), showed a significant response only to the sowing date, with less than one ear per plant in the first sowing date (0.96).

In the second sowing date, the result surpassed one ear per plant (1.03) due to the more favorable cultivation conditions, which are closely related to plant growth and development, and particularly related to the LAI, which was higher in the November-sown plants. This may also be related to water deficit, since the plant has apical dominance and, with photoassimilate reduction, prioritizes the tassel and the upper ear. A similar response was observed by Nascimento et al. (2011), in which the August sowing date resulted in a lower prolificity than the December sowing date.

Grain yield (Table 7) was influenced by the interaction between sowing date, hybrids, and growth regulators. The 2B610 PW hybrid showed a higher yield in the second sowing date, when better water conditions occurred for all growth regulatortreated plants. On the contrary, the 2B810PW hybrid showed no differences between the two dates, except for the plants treated with clomazone, which showed a higher productivity in the second date.

Table 7. Corn grain yield in response to hybrids, sowing dates, and growth regulators in the first corn cropping year. Londrina - PR, 2016.

\begin{tabular}{ccccccc}
\hline & \multicolumn{5}{c}{ Hybrids } \\
\hline \multirow{2}{*}{ Sowing dates } & $\begin{array}{c}\text { Trinexapac- } \\
\text { ethyl }\end{array}$ & \multirow{2}{*}{ Clomazine } & Control & $\begin{array}{c}\text { Trinexapac- } \\
\text { ethyl }\end{array}$ & Clomazine & Control \\
\cline { 2 - 7 } & \multicolumn{5}{c}{ Grain yield $\left(\mathrm{kg} \mathrm{ha}^{-1}\right)$} \\
\hline $1^{\text {st }}(09 / 19 / 2014)$ & $12102.83 \mathrm{~b} \alpha \mathrm{A}$ & $12573,07 \mathrm{~b} \alpha \mathrm{A}$ & $11398.45 \mathrm{~b} \alpha \mathrm{A}$ & $12037.37 \mathrm{a} \alpha \mathrm{A}$ & $10303.26 \mathrm{~b} \beta \mathrm{A}$ & $9023.29 \mathrm{a} \alpha \mathrm{A}$ \\
$2^{\text {nd }}(11 / 23 / 2014)$ & $17018.25 \mathrm{a} \alpha \mathrm{A}$ & $17577.25 \mathrm{a} \alpha \mathrm{A}$ & $18862.20 \mathrm{a} \alpha \mathrm{A}$ & $13703.60 \mathrm{a} \beta \mathrm{A}$ & $12632.37 \mathrm{a} \beta \mathrm{A}$ & $9807.21 \mathrm{a} \beta \mathrm{B}$ \\
\hline
\end{tabular}

*Averages followed by the same letter (lowercase for sowing dates, uppercase for growth regulators and Greek letters for hybrids) do not differ statistically by the $F$-test and Tukey's test, both at $5 \%$ probabilities.

In the comparison of hybrids there was equality between the trinexapac-ethyl and control treatments in the first date, but a higher grain yield was observed in the clomazone-treated 2B610PW hybrid. In the second sowing date, the $2 \mathrm{~B} 610 \mathrm{PW}$ hybrid was superior in all conditions, surpassing the grain yield of plants in the control treatment by $9 \mathrm{t}$.

The productive difference between genotypes is evident in the second sowing date in which environmental conditions were not restrictive. However, it is noteworthy that the non-differentiation observed at the first sowing date between genotypes is due to the grain mass compensation of the 2B810PW hybrid, which, even with its smaller leaf area and smaller number of grains per ear, did not have a significantly reduced yield.
The hybrid that stood out had a shorter cycle, with lower thermal need to reach flowering (860 GD), compared to that of 2B810PW (920 GD); however, contrary to what was expected, the development of the leaf area was equal in both (Table 3). Therefore, the difference in yield is due to the more efficient grain filling in the earlier plants, possibly due to the greater ability of the photoassimilates to be directed to the organ of economic interest, as well as the higher number of grains per ear, as shown in Tables 5 and 6.

Growth regulators was observed to have a significant effect only on the 2B810PW hybrid in the second sowing date, where the regulators provided a higher grain yield than the control. This is possibly due to the larger size of this hybrid, which 
was still stimulated by favorable environmental conditions in the second date, and was therefore more effectively influenced by growth regulators, which, by providing more compact plants, favored the interception of solar radiation and consequently grain filling in relation to the control.

In general, there was a numerical superiority of treatments containing growth regulators in relation to the control, except in the case of the $2 \mathrm{~B} 610 \mathrm{PW}$ hybrid in the second sowing date.

Moreover, in relation to the control, superiority was observed for clomazone of 1,175 and $1,280 \mathrm{~kg}$ $\mathrm{ha}^{-1}$ and trinexapac-ethyl of 704 and $3,014 \mathrm{~kg} \mathrm{ha}^{-1}$ for 2B610PW and 2B810PW hybrids, respectively, at the first sowing date. Furthermore, in the second sowing date, the 2B810PW hybrid obtained 2,825 and $3,893 \mathrm{~kg} \mathrm{ha}^{-1}$ more for clomazone and trinexapac-ethyl treatments, respectively, in relation to control without application.

The positive result obtained with the use of clomazone is related to its inhibitory action on diterpenes biosynthesis, which consequently decreases the production of gibberellin and had its action on growth (stem) and effect on grain yield by changing the source-drain relationship.

The present result of trinexapac-ethyl is related to that observed by Pricinotto (2014), who reported that the higher grain yield was related to the higher interception efficiency of solar radiation by plants treated with growth regulator, apparently by an architectural modification in which the leaves were arranged upright, which consequently increased their biological efficiency.

However, the aforementioned study obtained an increase in yield with the use of trinexapac-ethyl associated with higher plant densities, which was not tested in the present study. Therefore, the favorable response only from regulators makes it even more viable to obtain an increase in the yield potential of corn, suggesting that this technology could result in the possibility of using higher population densities.
Zagonel and Ferreira (2013), when evaluating the effect of trinexapac-ethyl at doses and application times on two corn hybrids, observed an increased width and decreased leaf length with increasing compound doses for one hybrid, without substantial effects on the production components and yield. Pricinotto et al. (2015) found a reduction in grain yield per plant in greenhouse study. Considering the results reported by these authors, as well as those obtained at different sowing dates in this study, it is evident that the effect of growth regulators depends on the interaction with management factors.

Sowing date is the main factor among all characteristics analyzed, especially grain yield. It can be considered that two distinct crop environments were evaluated, since in the case of early sowing in September, the occurrence of water deficiency at the beginning of the cycle significantly affected plant development, with an effective reduction of the photosynthetically active area and, as a consequence, grain yield per hectare.

The performance of hybrids and growth regulators, as well as their interaction, is directly affected by environmental factors. These conditions require further studies to provide better results for this investigation, so that in the future, recommendations can be made for the use of regulators based on genotypes and growing environments.

According to Bergamaschi and Matzenauer (2014), one of the immediate consequences of water deficiency is decreased cell expansion, which causes a reduction in the leaf area. This causes a decrease in the plant growth rate, particularly during the early stages of growth; as a consequence, the lower interception of solar radiation, and this lower vegetative performance, ultimately results in the reduction of grain yield, which is of economic interest.

Regarding growth regulators, trinexapacethyl dependence on suitable water conditions for obtaining compact plants stands out, thus enabling its use in densified spatial arrangements of corn; 
however, in this restrictive condition, the compost may act in other physiological aspects, such as reducing respiration in plants. Moreover, there is variable effect on genotype, with a productive increase for $2 \mathrm{~B} 810 \mathrm{PW}$ and reduction for $2 \mathrm{~B} 610 \mathrm{PW}$ when the environment is not restrictive, which indicates the need for more evaluations, with more genotypes and edaphoclimatic conditions, in order to support future recommendations of this regulator.

The clomazone compound was effective in modifying plant stem size and diameter, which were also influenced by the environmental condition and genotype. Its effect on the greater number of grains produced and the good yield performance is noteworthy, especially at the first sowing date, when the water deficiency reduced the yield of the control and trinexapac-ethyl-treated plants more effectively.

\section{Conclusions}

The corn development and yield were altered by interactions between sowing dates, hybrids, and growth regulators.

The second sowing date, in which plants were not limited by water deficit, resulted in better development and yield performance for both hybrids.

The 2B610PW hybrid had a higher yield performance than the $2 \mathrm{~B} 810 \mathrm{PW}$ in the second sowing date.

Trinexapac-ethyl and clomazone contributed to corn grain yield for the two hybrids at the first sowing date and only the 2B810PW hybrid in the second date. Trinexapac-ethyl caused a size reduction in the 2B810PW hybrid in the second sowing date.

The growth and leaf area of the 2B810PW hybrid were less affected by the restrictive condition of the first sowing date; consequently, there was a higher grain weight performance that does not allow the differentiation of yield between genotypes for this sowing date.

\section{References}

ARGENTA, G.; SILVA, P. R. F.; MIELNICZUK, J.; BORTOLINI, C. G. Parâmetros de planta como indicadores do nível de nitrogênio na cultura do milho. Pesquisa Agropecuária Brasileira, Brasília, v. 37 , n. 4 , p. $519-527,2002$. DOI:10.1590/S0100204X2002000400014.

BERGAMASCHI, H.; DALMAGO, G. A.; BERGONCI, J. I.; KRÜGER, C. A. M. B.; HECKLER, B. M. M.; COMIRAN, F. Intercepted solar radiation by maize crops subjected to diferent tillage systems and water availability levels. Pesquisa Agropecuária Brasileira, Brasília, v. 45, n. 12, p. 1331-1341, 2010. DOI: 10.1590/ S0100-204X2010001200001.

BERGAMASCHI, H.; MATZENAUER, R. $O$ milho e $o$ clima. Porto Alegre: Emater/RS, 2014. 81 p.

BRASIL. Regras para análise de sementes. Brasília: Ministério da Agricultura, Pecuária e Abastecimento, 2009.

COSTA, J. R. D.; PINHO, J. L. N. D.; PARRY, M. M. Produção de matéria seca de cultivares de milho sob diferentes níveis de estresse hídrico. Revista Brasileira de Engenharia Agrícola e Ambiental, Campina Grande, v. 12 , n. 5 , p. $443-450$, 2008. DOI: $10.1590 / \mathrm{S} 1415-$ 43662008000500001 .

COSTA, K. D. D. S.; CARVALHO, I. D. E. de; FERREIRA, P. V.; SANTOS, P. R. dos; SOUZA, E. G. F.; SOUSA, T. P. Avaliação de genótipos de milho em diferentes densidades populacionais. Agropecuária Científica no Semiarido, Campina Grande, v. 11, n. 1, p. 27-36, 2015. DOI: 10.30969/acsa.v11i3.602.

DAVIES, P. J. The plant hormones: their nature, occourrence, and functions. In: DAVIES, P. J. Plant hormones and their role in plant growth and development. Switzerland: Kluwer Academic, 1987. p. 1-23.

EMPRESA BRASILEIRA DE PESQUISA AGROPECUÁRIA - EMBRAPA. Sistema brasileiro de classificação de solos. 3. ed. rev. ampl. Brasília: EMBRAPA, 2013. 353 p.

EMPRESA BRASILEIRA DE PESQUISA AGROPECUÁRIA - EMBRAPA. Sistemas de produção: cultura do milho. 8. ed. Sete Lagoas-MG: Editora Embrapa, out. 2012. Disponível em: http:// sistemasdeproducao.cnptia.embrapa.br/FontesHTML/ Milho/CultivodoMilho_7ed/autores.htm. Acesso em: 2 jul. 2015.

FAGHERAZZI, M. M. Respostas morfo-agronômicas do milho a aplicação de trinexapac-ethyl em diferentes estádios fenológicos e doses de nitrogênio. 2015. 
Dissertação (Mestrado em Produção Vegetal) - Centro de Ciências Agroveterinárias, Universidade do Estado de Santa Catarina, Lages.

FERNANDES, A. C. População de plantas e regulador de crescimento afetando a produtividade de cultivares de trigo. 2009. Dissertação (Mestrado em Agronomia) Universidade Estadual de Ponta Grossa, Ponta Grossa.

FOLONI, J. S. S.; CALONEGO, J. C.; CATUCHI, T. A.; BELlEGGIA, N. A.; TIRITAN, C. S.; BARBOSA, A. D. M. Cultivares de milho em diferentes populações de plantas com espaçamento reduzido na safrinha. Revista Brasileira de Milho e Sorgo, Sete Lagoas, v. 13, n. 3, p. 312-325, 2015. DOI:10.18512/1980-6477/rbms. v13n3p312-325

FRANÇA, S.; BERGAMASCHI, H.; ROSA, L. M. G. Modelagem do crescimento de milho em função da radiação fotossinteticamente ativa e do acúmulo de graus-dia, com e sem irrigação. Revista Brasileira de Agrometeorologia, Santa Maria, v. 7, n. 1, p. 59-66, 1999.

FRANCIS, C. A.; RUTGER, J. N.; PALMER, A. F. E. A. Rapid method for plant leaf area estimation in maize (Zea mays). Crop Science, Madison, v. 9, n. 5, p. 537539, 1969. DOI: 1969.0011183X000900050005x.

HAWERROTH, M. C.; SILVA, J. A. G. da; SOUZA, C. A.; OLIVEIRA, A. C. de; SOUZA LUCHE, H. de; ZIMMER, C. M.; HAWERROTH, F. J.; SCHIAVO, J.; SPONCHIADO, J. C. Redução do acamamento em aveia-branca com uso do regulador de crescimento etil-trinexapac. Pesquisa Agropecuária Brasileira, Brasília, v. 50, n. 2, p. 115-125, 2015. DOI: 10.1590/ S0100-204X2015000200003.

HECKMAN, N. L.; ELTHON, T. E.; HORST, G. L.; GAUSSOIN, R. E. Influence of trinexapac-ethyl on respiration of isolated wheat mitochondria. Crop Science, Madison, v. 42, n. 2, p. 423-427, 2002.

KERBAUY, G. B. Fisiologia vegetal. Rio de Janeiro: Guanabara Koogan, 2004. 453 p.

MACIEL, C. D. G.; POLETINE, J. P.; RAIMONDI, M. A.; RODRIGUES, M.; RIBEIRO, R. B.; COSTA, R. S.; MAIO, R. M. D. Desenvolvimento de gramados submetidos à aplicação de retardadores de crescimento em diferentes condições de luminosidade. Planta Daninha, Viçosa, MG, v. 29, n. 2, p. 383-395, 2011. DOI: 10.1590/S0100-83582011000200016.

MARCHÃO, R. L.; BRASIL, E. M.; DUARTE, J. B.; GUIMARÃES, C. M.; GOMES, J. A. Densidade de plantas e características agronômicas de híbridos de milho sob espaçamento reduzido entre linhas. Pesquisa Agropecuária Tropical, Goiânia, v. 35, n. 2, p. 93-101, 2005.
MORO, J. R.; CASTRO, P. R. C. Ação de reguladores vegetais na morfologia e produtividade do milho (Zea mays L.). Revista de Agricultura, Piracicaba, v. 59, n. 3, p. 301-311, 1984.

NASCIMENTO, F. M.; BICUDO, S. J.; RODRIGUES, J. G. L.; FURTADO, M. B.; CAMPOS, S. Produtividade de genótipos de milho em resposta à época de semeadura. Revista Ceres,Viçosa, MG, v. 58, n. 2, p. 193-201, 2011.

OLIVEIRA, L. R., MIRANDA, G. V., DELIMA, R. O., FRITSCHE-NETO, R., GALVÃO, J. C. C. Eficiência na absorção e utilização de nitrogênio e atividade enzimática em genótipos de milho. Revista Ciência Agronômica, Fortaleza, v. 44, n. 3, p. 614-621, 2013.

PAGLIOSA, E. E.; BENIN, G.; BIEZUS, E.; BECHE, E.; SILVA, C.; MARCHESE, J.; MARTIN, T. Trinexapacethyl and nitrogen fertilization rates in wheat crop. Planta Daninha, Viçosa, MG, v. 31, n. 3, p. 623-630, 2013. DOI: 10.1590/S0100-83582013000300014.

PRICINOTTO, L. F. Densidades populacionais $e$ regulador de crescimento em hibridos de milho com diferentes arquiteturas. 2014. Tese (Doutorado em Agronomia) - Universidade Estadual de Londrina, Londrina.

PRICINOTTO, L. F.; ZUCARELI, C.; FONSECA, I. C. B.; OLIVEIRA, M. A.; FERREIRA, A. S.; SPOLAOR, L. T. Trinexapac-ethyl in the vegetative and reproductive performance of corn. African Journal of Agricultural Research, Nairobi, v. 10, n. 14, p. 1735-1742, 2015. DOI: 10.5897/AJAR2014.8613.

RADEMASCHER, W. Plant growth regulators: backgrounds and uses in plant production. Journal of Plant Growth Regulators, Switzerland, v. 34, n. 4, p. 845872, 2015. DOI: 10.1007/s00344-015-9541-6.

RITCHIE, S. W.; HANWAY, J. J.; BENSON, G. O.; HERMAN, J. C. How a corn plant develops. Iowa: Iowa State University of Science and Technology, Cooperative Extension Service, 1993. 21 p.

SANGOI, L.; SILVA, P. R. F.; ARGENTA, G.; RAMBO, L. Ecofisiologia da cultura do milho para altos rendimentos. Lages: Graphel, 2010. 87 p.

SOUZA, G. M.; CATUCHI, T. C.; BERTOLLI, S. C.; SORATTO, R. P. Soybean under water deficit: physiological and yield responses, a comprehensive survey of international soybean research - genetics, physiology, agronomy and nitrogen relationships, James E. Board, IntechOpen, 2013. 27 p. DOI: 10.5772/54269.

STRECK, N. A.; SILVA, S. D. D.; LANGNER, J. A. Assessing the response of maize phenology under elevated temperature scenarios. Revista Brasileira de 
Meteorologia, São José dos Campos, v. 27, n. 1, p. 1-12, 2012. DOI: $10.1590 / \mathrm{S} 0102-77862012000100001$.

TAIZ, L.; ZEIGER, E. Fisiologia vegetal. 4. ed. Porto Alegre: Editora Artmed, 2009. 820 p.

WAGNER, M. V.; JADOSKI, S. O.; MAGGI, M. F.; SAITO, L. R.; LIMA, A. S. Estimativa da produtividade do milho em função da disponibilidade hídrica em Guarapuava, PR, Brasil. Revista Brasileira de Engenharia Agrícola e Ambiental, Campina Grande, v. 17 , n. 2 , p. 170-179, 2013. DOI: 10.1590/S141543662013000200008 .

ZAGONEL, J.; FERREIRA, C. Rates and times of growth regulator application on corn hybrids. Planta Daninha, Viçosa, MG, v. 31, n. 2, p. 395-402, 2013. DOI: 10.1590/S0100-83582013000200017.
ZAGONEL, J.; VENANCIO, W. S.; KUNZ, R. P.; TANAMATI, H. Doses de nitrogênio e densidade de 199 plantas com e sem um regulador de crescimento afetando o trigo, cultivar OR-1. Ciência Rural, Santa Maria, v. 23, n. 1, p. 25-29, 2002. DOI: 10.1590/S010384782002000100005 .

ZHANG, Q.; ZHANG, L.; EVERS, J.; VAN DER WERF, W.; ZHANG, W.; DUAN, L. Maize yield and quality in response to plant density and application of a novel plant growth regulator. Field Crops Research, v. 164, n. 1, p. 82-89, 2014. DOI: 10.1016/j.fcr.2014.06.006. 